ISSN 0081-7147

e-ISSN 2451-1331

Marek L. WÓJCIK

https://orcid.org/0000-0002-2009-5559

Uniwersytet Wrocławski

\title{
Śląska pieczęć Jana Hinczy z Rogowa z 1435 r. Przyczynek do dziejów herbu Działosza
}

Zarys treści: Przedmiotem zainteresowania autora jest nieznana w historiografii pieczęć podskarbiego koronnego Jana Hinczy z Rogowa, odnaleziona w Archiwum Państwowym we Wrocławiu przy dokumencie z 1435 r. Ze względu na unikalny kształt godła stała się ona punktem wyjścia do badań nad najstarszym, wiązanym genetycznie ze Śląskiem, wyobrażeniem herbu Działosza i jego ewolucją.

Abstract: The author focuses his interest on the seal of Crown Treasurer Jana Hincza of Rogów, unknown in historiography, found in the State Archives in Wrocław applied to a document of 1435. Due to the unique shape of its charge, it has become the starting point for research on the oldest, genetically related to Silesia, image of the coat of arms of Działosza and its evolution.

Słowa kluczowe: pieczęć, herb, Rogowscy, Działosza, Śląsk, Salisch

Keywords: seal, coat of arms, the Rogowski family, Działosza, Silesia, Salisch

Jan Hincza (ok. 1400-1474) herbu Działosza, piszący się z Rogowa koło Opatowca, to postać doskonale znana w historiografii ${ }^{1}$. Rozgłos zyskał już u współczesnych, bynajmniej nie tylko z powodu osiągniętych zaszczytów, piastowanych urzędów, zdobytego bogactwa czy też sukcesów w działalności politycznej, gospodarczej i fundacyjnej, ale także ze względu na skandal obyczajowy, jaki wywołał w 1427 r., wdając się rzekomo w romans z Zofią Holszańską, czwartą żoną Władysława Jagiełły. Nie on sam zresztą, jak bowiem relacjonuje niechętny Zofii Jan Długosz - cudzołóstwa królowa miała się dopuścić także z Piotrem Kurowskim, Wawrzyńcem Zarembą z Kalinowy, Janem Kraską z Łubnicy, Janem Taszką z Koniecpola oraz braćmi Piotrem i Dobiesławem ze Szczekocin ${ }^{2}$. Zarzuty o utrzymywanie przez monarchinię intymnych kontaktów z rycerzami jej dworu okazały się wprawdzie całkowicie

\footnotetext{
1 J. Senkowski, T. Słowikowski, Hincza (Henryk) z Rogowa (zm. 1473), w: PSB, t. 9, Kraków-Wrocław 1960-1961, s. 521-523; J. Kalinowska, Jan Hincza z Rogowa i jego działalność fundacyjna na dworze pierwszych Jagiellonów, „Analecta Cracoviensia”, 19, 1987, s. 319-341; taż, Kaplica Jana Hinczy w Katedrze na Wawelu i jej malowidła ścienne, „Studia do Dziejów Wawelu”, 5, 1991, s. 133-235; B. Czwojdrak, Rogowscy herbu Działosza podskarbiowie królewscy. Studium z dziejów możnowładztwa $w$ drugiej połowie XIV $i$ w XV wieku, Katowice 2002, s. 56-98, 195-202; taż, Zofia Holszańska. Studium o dworze i roli królowej w późnośredniowiecznej Polsce, Warszawa 2012, s. 137-140.

2 Joannis Dlugossi Annales seu Cronicae incliti Regni Poloniae, lib. 11: 1413-1430, red. J. Wyrozumski, Varsaviae 2000, s. 226-228; J. Długosz, Roczniki czyli kroniki sławnego Królestwa Polskiego, ks. 11: 1413-1430, red. S. Gawęda, thum. J. Mrukówna, Warszawa 2009, s. 238-240.
} 
bezpodstawne, jednak bliskich więzi, jakie łączyły z nią Jana Hinczę, wykraczających poza zwykłe relacje między władczynią i poddanym, nie sposób całkowicie wykluczyć3 ${ }^{3}$.

Oskarżenia, których ofiarą padł Jan Hincza, nie przeszkodziły mu w karierze, aczkolwiek rozpoczął ją, będąc już w sile wieku. Na swój pierwszy urząd - starosty radomskiego - przyszło mu wszak czekać aż do 1440 r. Miał wtedy ok. 40 lat. Odtąd jednak jego kariera, którą zawdzięczał zarówno Zofii Holszańskiej, jak i jej synom, królom Władysławowi i Kazimierzowi, potoczyła się błyskawicznie. Pod koniec 1442 lub na początku 1443 r., dzierżąc nadal starostwo radomskie (do 1461), został kasztelanem rozpierskim, w 1453 r. zaś przeszedł na kasztelanię sieradzką, by 7 lat później zamienić ją ostatecznie na kasztelanię sandomierską. Na tej ostatniej zasiadał aż do śmierci (4 II 1474)4. Jednocześnie piastował funkcje starosty nieszawsko-inowrocławskiego (1452-1474), golubskiego (1472-1474) i chęcińskiego (1472-1474). W latach 1447-1460 sprawował także urząd podskarbiego królewskiego, ponadto był tenutariuszem brzeźnickim, pyzdrskim, krzepickim i kolskim5. Wszystkie te godności i zaszczyty przyniosły mu ogromne bogactwo. O ile u progu działalności publicznej należało do niego w Koronie tylko kilka wsi położonych w ziemiach wieluńskiej, sieradzkiej i krakowskiej, odziedziczonych w części po ojcu, Hinczce z Roszkowic, o tyle w ciągu życia stał się właścicielem dwóch miast (Koźmina i Działoszyna), dwóch zamków (Koźmina i Mirowa), ok. 50 wsi, w tym trzech zwartych kluczy majątkowych (działoszyńskiego, koźmińskiego i mirowskiego) oraz kilkunastu osad rozproszonych w okolicach Koła, Pyzdr i Sieradza, a także domów w Krakowie, Nowym Mieście Korczynie i Toruniu. Majątek możnowładcy uzupełniały dodatkowo tenuty i wsie królewskie oraz dzierżawy dóbr kościelnych ${ }^{6}$. Dzięki służbie monarchii stał się bez wątpienia jednym z najmożniejszych ludzi swoich czasów.

Miarą jego zamożności były liczne fundacje i darowizny na cele religijne, będące przejawem typowej średniowiecznej pobożności, w jego przypadku nadzwyczaj hojne, ponieważ z małżeństwa z Dorotą z Koziegłów herbu Lis, poślubioną ok. 1445-1446 r., nie doczekał się potomstwa, któremu mógłby przekazać w spadku zgromadzony majątek ${ }^{7}$. Jego dziełem były założenia klasztorne kanoników regularnych św. Augustyna w Krzepicach oraz bernardynów w Kole. Podjął również próbę osadzenia paulinów w Dankowie, jednak z nieznanych bliżej przyczyn fundacja ta nie doszła do skutku. Wzniósł kościoły w kilku swoich wsiach - w Parzymiechach, Rogowie, Szczytach i Trębaczewie (dziś Trębaczów). Był darczyńcą i donatorem klasztorów bernardynek, bernardynów i dominikanów w Krakowie, bożogrobców w Miechowie oraz kanoników regularnych laterańskich w Mstowie. Uposażył kościoły w Kole, Koźminie, Krakowie, Poznaniu, Szamotułach i Toruniu oraz krakowskie szpitale i leprozoria8. Ufundował także prywatną kaplicę grobową w katedrze na Wawelu (która od złożonych w niej relikwii św. Niewiniątek funkcjonowała pod ich wezwaniem, ale powszechnie znana była jako kaplica Hinczów), w której został po śmierci pochowany i do której jeszcze za życia przeniósł doczesne szczątki

3 Tak właśnie stawia sprawę B. Czwojdrak, Rogowscy, s. 57-60, 153, 162-165; taż, Jan Hincza z Rogowa - rycerz królowej Zofii, w: Faworyci i opozycjoniści. Król a elity polityczne w Rzeczypospolitej XV-XVIII wieku, red. M. Markiewicz, R. Skowron, Kraków 2006, s. 61-66; taż, Miłość i polityka w kręgach dworu królewskiego - królowa Zofia Holszańska i jej rycerze, w: Miłość w czasach dawnych, red. B. Możejko, A. Paner, Gdańsk 2009, s. 121-129; taż, Zofia Holszańska, s. 137-140. Odmienny punkt widzenia prezentuje natomiast W. Zawitkowska, Niewierność matżeńska królowej Zofii Holszańskiej w 1427 r. - prawda, pomówienie czy plotka polityczna? Próba rekonstrukcji wydarzeń na tle oskarżeń innych żon Jagiełty, Kwart. Hist., 123, 2016, nr 1, s. 5-43, która kwestionuje bliskie związki Jana Hinczy z królową.

${ }^{4}$ W starszej historiografii przyjmowano, że Jan Hincza zmarł 29 IX 1473, datę tę podają bowiem nekrolog kanoników regularnych przy kościele Bożego Ciała w Krakowie oraz akta kapituły katedralnej; zob. m.in. J. Senkowski, T. Słowikowski, Hincza (Henryk) z Rogowa, s. 523; J. Kalinowska, Jan Hincza, s. 327; taż, Kaplica Jana Hinczy, s. 140, 220 , przyp. 75. Ostatnie badania wykazały jednak, że śmierć Rogowskiego nastąpiła 4 II 1474; zob. B. Czwojdrak, Rogowscy, s. $197-200$.

${ }^{5}$ Karierę Jana Hinczy skrupulatnie prześledziła B. Czwojdrak, Rogowscy, s. 56-98. Tam także pełna dokumentacja źródłowa.

${ }^{6}$ Dokładne zestawienie majątków Rogowskich, w tym Jana Hinczy, pozostających w jego rękach zarówno na stałe, jak i w użytkowaniu czasowym, zob. tamże, s. 120-149.

7 Tamże, s. 201-202.

${ }^{8}$ Szerzej na temat działalności fundacyjnej Jana Hinczy wypowiedziały się J. Kalinowska, Jan Hincza, s. 319-341; B. Czwojdrak, Rogowscy, s. 150-165. O próbie założenia klasztoru paulinów w należącym do niego Dankowie zob. też taż, Paulini w Dankowie - nieudana fundacja Jana Hinczy z Rogowa, w: Veritati serviens. Księga pamiątkowa Ojcu Profesorowi Januszowi Zbudniewkowi zp, red. J. Dzięgielewski, Warszawa 2009, s. 365-368. 
ojca i starszego brata Henryka9. Wydaje się, że nie było w późnośredniowiecznej Polsce drugiego tak hojnego dla instytucji kościelnych fundatora ${ }^{10}$. Z całą pewnością chybiona jest więc opinia Długosza, jakoby przedstawicieli Działoszów cechowało skąpstwo: ,genus [...] tenacitatem redolens”"11.

Jest rzeczą zdumiewającą, że pomimo aktywnej, trwającej pół wieku działalności publicznej, zamykającej się w latach 1423-1474, mierzonej nie tylko wspomnianymi wyżej dokonaniami, ale także ogólną liczbą wystąpień źródłowych i wystawionych dokumentów, po Janie Hinczy zachowało się bardzo niewiele pieczęci, które są ponadto - jak twierdzi Bożena Czwojdrak, znawczyni genealogii Rogowskich - jedynymi znanymi z terenu Korony pieczęciami należącymi do przedstawicieli tej właśnie familii. Odnotowała ona zaledwie dwa ich egzemplarze: starszy, z 1455 r., poręczający wraz z 15 pieczęciami dygnitarzy koronnych zobowiązanie Kazimierza Jagiellończyka do zwrotu w ciągu 4 lat kościołom diecezji gnieźnieńskiej kosztowności (lub ich równowartości) przekazanych królowi na potrzeby obrony kraju i wykupu jeńców z niewoli w dobie konfliktu z Krzyżakami ${ }^{12}$, oraz młodszy, z 1466 r., przywieszony przy dokumencie strony polskiej drugiego pokoju toruńskiego jako jeden ze 114 odcisków należących do jego gwarantów $^{13}$. Badaczka nie zajęła się nimi bliżej, informując tylko, że są to pieczęcie herbowe z wyobrażeniem herbu Działosza ${ }^{14}$. Ich autopsja pozwala stwierdzić, że zostały wyciśnięte za pomocą tego samego tłoka. Oba odciski, okrągłe, mają wszak tę samą wielkość, tj. ok. $23 \mathrm{~mm}$ średnicy, i eksponują tożsamy, niewykazujący między sobą żadnych różnic, wizerunek. W polu pieczęci widnieje gotycka tarcza herbowa typu hiszpańskiego, a więc o łagodnie zaokrąglonej podstawie, na niej zaś godło Działoszów - róg jeleni o pięciu rosochach i orle skrzydło w słup ${ }^{15}$. Herb okala trójdzielna wstęga przepleciona przez trójłukową rozetę $\mathrm{z}$ napisem rytym minuskułą gotycką $\mathrm{w}$ brzmieniu: $+\mathrm{s} \circ$ hincza ${ }^{\circ}$ de ${ }^{\circ}$ rogow ${ }^{16}$ (zob. il. 1).

Za pomocą tego samego typariusza wykonano też odcisk, pomijany dotąd przez badaczy, który zachował się w zbiorze luźnych pieczęci Archiwum Narodowego w Krakowie, datowany - co prawda przez archiwistów na 1473 r. ${ }^{17}$, ale niewykluczone, że będący nieco starszym (zob. il. 2). W inwentarzu

9 J. Kalinowska, Jan Hincza, s. 327-338; taż, Kaplica Jana Hinczy, s. 133-235; B. Czwojdrak, Rogowscy, s. 162-165, 192, 194, 202.

10 Por. Z. Zyglewski, Klasztorne fundacje możnowładztwa koronnego w okresie jagiellońskim. Zarys problematyki, w: Klasztor $w$ społeczeństwie średniowiecznym i nowożytnym. Materiały z międzynarodowej konferencji naukowej zorganizowanej w Turawie w dniach 8-11 V 1996 przez Instytut Historii Uniwersytetu Opolskiego i Instytut Historyczny Uniwersytetu Wrocławskiego, red. M. Derwich, A. Pobóg-Lenartowicz, Opole-Wrocław 1996, s. 127-142.

${ }^{11}$ Klejnoty Dlugoszowe, oprac. i wyd. M. Friedberg, Rocz. Herald., 10, 1930 [dalej: Klejnoty], s. 61.

${ }^{12}$ BCzart., Dokumenty pergaminowe, nr 520. Przy dokumencie przywieszonych było pierwotnie 17 pieczęci (królewska i 16 należących do poręczycieli układu), z których do dziś zachowały się tylko cztery, w tym (luzem, oderwana od pergaminu) Jana Hinczy; zob. C. epist. XV, t. 3: 1392-1501, wyd. A. Lewicki, Kraków 1894, nr 69 (s. 85); W. Szelińska, J. Tomaszewicz, Katalog dokumentów pergaminowych Biblioteki Czartoryskich w Krakowie, cz. 1: Dokumenty z lat 1148-1506, Kraków 1975, nr 571 (s. 246). Słabej jakości reprodukcję pieczęci Jana Hinczy, uniemożliwiającą identyfikację wizerunku i odczyt legendy, publikuje B. Czwojdrak, Rogowscy, wklejka po s. 64, fot. 1.

13 AGAD, Zbiór dokumentów pergaminowych, nr 1140. Dziś przy dokumencie zachowały się jedynie 53 pieczęcie, a dwie kolejne, oderwane, są przechowywane w zbiorze pieczęci luźnych; zob. P. Nowak, Dokumenty II pokoju toruńskiego z 1466 r., St. Źródł., 43, 2005, s. 105. O Janie Hinczy jako jednym z gwarantów traktatu z 1466 r. zob. A. Gąsiorowski, Polscy gwaranci traktatów z Krzyżakami XIV-XV w., „Komunikaty Mazursko-Warmińskie”, 1971, nr 2-3, s. 259. Pieczęć Jana Hinczy omawiają i reprodukują: M. Grzegorz, Analiza dyplomatyczno-sfragistyczna dokumentów traktatu toruńskiego 1466 r., Torun 1970, nr 29, s. 116 (tutaj opis, jednak z mylną informacją o bawolim rogu i orlim piórze w godle) i ryc. 19 (reprodukcja) oraz B. Czwojdrak, Rogowscy, s. 24-25, przyp. 9 i s. 4 okładki.

${ }_{14}$ B. Czwojdrak, Rogowscy, s. 20, przyp. 24; s. 24, przyp. 9; s. 94, przyp. 298 (tutaj z mylną sygnaturą AGAD, Zbiór dokumentów pergaminowych, nr 1143, którą oznaczony jest dokument drugiego pokoju toruńskiego z 1466 r. uwierzytelniony pieczęciami gwarantów strony krzyżackiej; zob. T. Karczewska, Przegląd pieczęci pruskich z dokumentów traktatu toruńskiego z 1466 r., „Komunikaty Mazursko-Warmińskie”, 1962, nr 4, s. 753-779; M. Grzegorz, Analiza dyplomatyczno-sfragistyczna, s. 86-88, 132-133, 166-167; P. Nowak, Dokumenty, s. 104).

15 J. Szymański, Herbarz średniowiecznego rycerstwa polskiego, Warszawa 1993, s. 120.

${ }^{16}$ M. Grzegorz, Analiza dyplomatyczno-sfragistyczna, s. 116, odczytał tylko fragment legendy, w dodatku z błędnym incipitem, jako „s + hinc... de rogo.”. Niewłaściwą lekcję podał także co do egzemplarza z 1455 r. A. Lewicki, w: C. epist. $\mathrm{XV}$, t. 3, s. 85, który - biorąc najpewniej ostatni dywizor w kształcie kółka za literę „o" - odczytał inskrypcję w wersji „s. hincza de rogovo".

${ }^{17}$ AN, Zbiór luźnych pieczęci, sygn. 29/1597/0/-/92. 


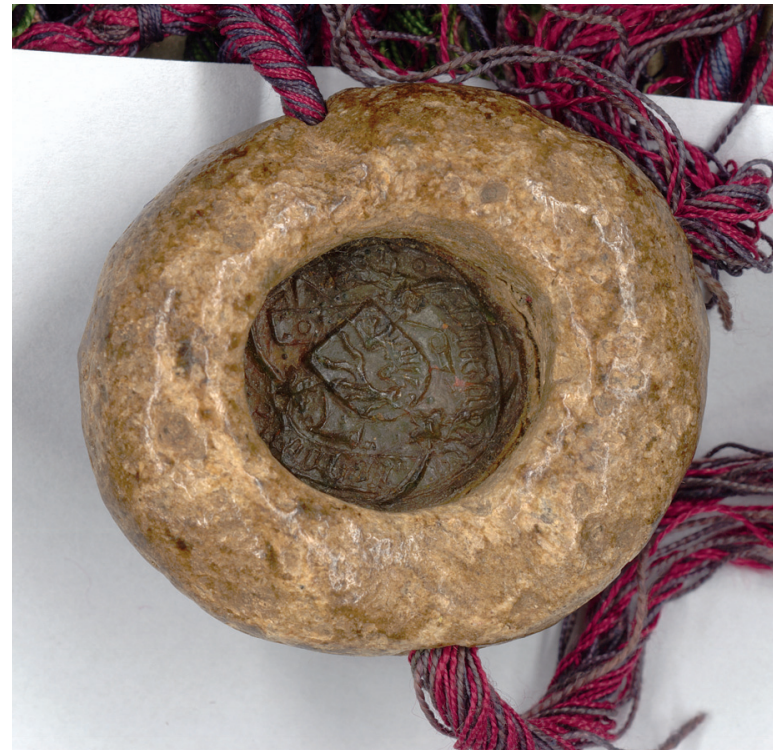

Il. 1. Pieczęć Jana Hinczy z Rogowa, 1466 r.; AGAD, Zbiór dokumentów pergaminowych, $\mathrm{nr} 1140$

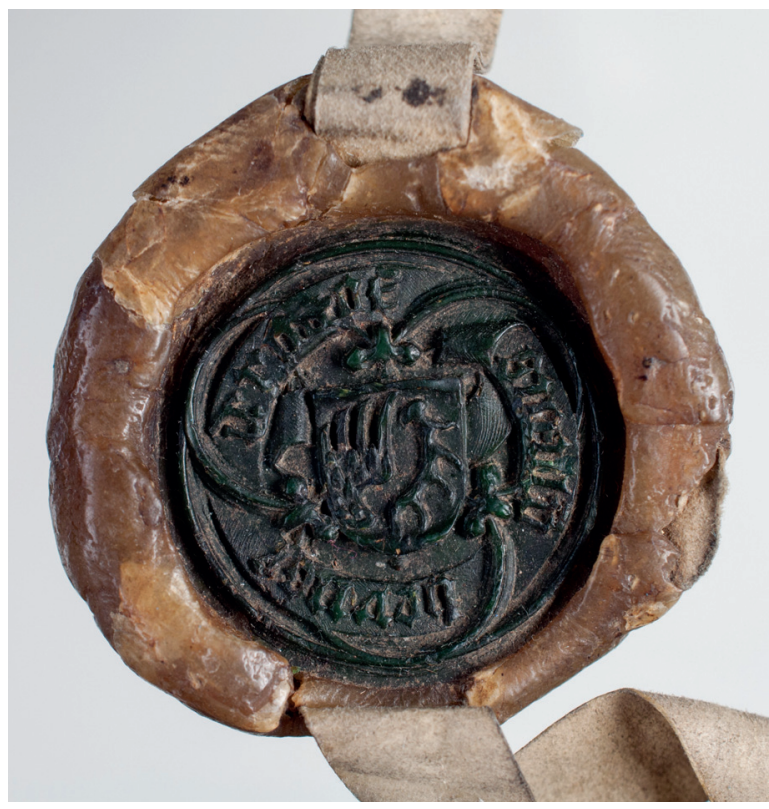

Il. 3. Śląska pieczęć Jana Hinczy z Rogowa, 1435 r.; AP Wrocław, Rep. 3 nr 32 (28), fot. Ryszard Bacmaga

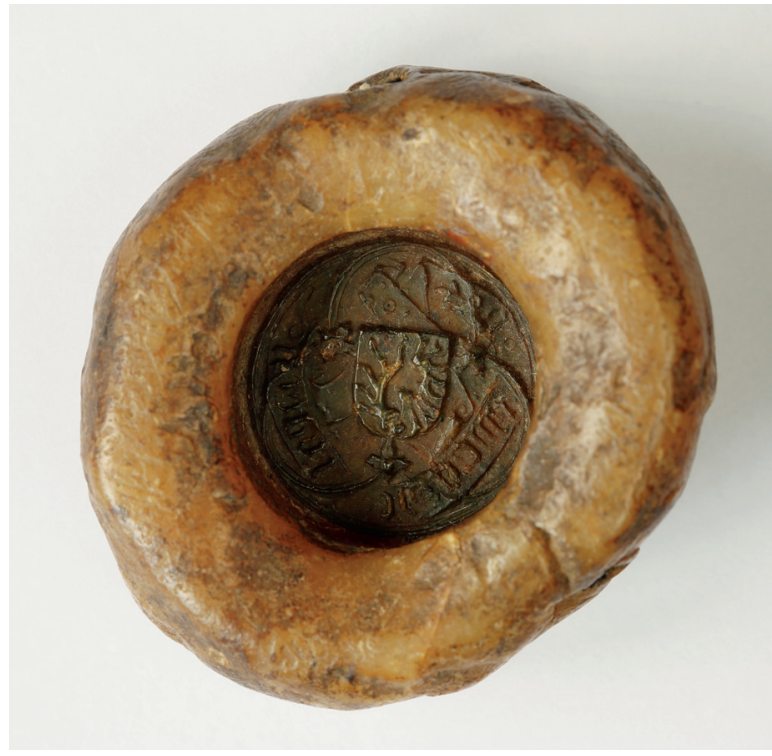

Il. 2. Pieczęć Jana Hinczy z Rogowa, 1473 r.; AN, Zbiór luźnych pieczęci, sygn. 29/1597/0/-/92

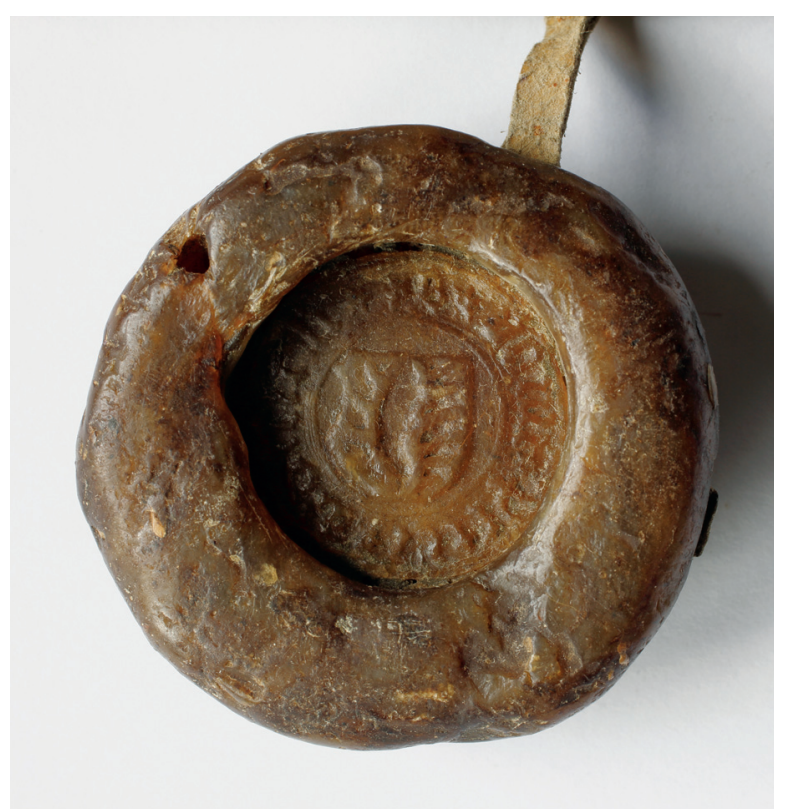

Il. 4. Pieczęć Piotra Wołczkowica, 1456 r.; AN, Zbiór Rusieckich. Dokumenty pergaminowe, nr 140 
odlewów pieczęci pochodzących ze zbiorów Franciszka Piekosińskiego przekazanych Bibliotece Ossolineum we Lwowie odnotowany został bowiem nieznany w historiografii egzemplarz okrągłej pieczęci Jana Hinczy, której oryginał wisieć miał na sznurku ,z białego i pąsowego i szafirowego jedwabiu” przy dokumencie z 1472 r. przechowywanym pod koniec XIX stulecia w archiwum miejskim krakowskim $^{18}$. Dokumentu tego nie udało się odnaleźć. Przypuszczalnie chodziło o pieczęć wzmiankowaną przez właściciela kolekcji w innym miejscu, gdzie nie podał on wprawdzie, z którego roku pochodził jej odcisk, ale wyraźnie zaznaczył, że była użyta w okresie sprawowania przez Jana Hinczę urzędu kasztelana sandomierskiego ${ }^{19}$. Odcisk z 1472 r. spełnia ten warunek, wspomnianą godność Jan Hincza pełnił bowiem - przypomnijmy - w latach 1460-1474. Podany w inwentarzu opis pieczęci: „w tarczy herb Działosza. Naokoło w trójłucznej obwódce przeciągnięta wstęga z napisem: $\bullet \circ:+\mathrm{s} \circ$ hincza - de $\circ$ rog $\circ$ ov o" odpowiada wizerunkowi i legendzie (przypuszczalnie z błędem odczytu ostatniego słowa) widocznym na omówionych wyżej pieczęciach z 1455 i $1466 \mathrm{r}^{20}$ Niezależnie zresztą od tego, czy zachowana $\mathrm{w}$ archiwum krakowskim pieczęć jest tożsama $\mathrm{z}$ sigillum opisanym w zbiorze F. Piekosińskiego, czy też chodzi o dwa różne odciski z lat 1472-1473, to liczba zachowanych do dziś oryginalnych pieczęci Jana Hinczy znanych z ziem koronnych sięga zaledwie trzech egzemplarzy, co tylko potwierdza opinię o ogromnej dysproporcji między długoletnią i aktywną działalnością publiczną dygnitarza a ocalałą po nim spuścizną sfragistyczną. Tłoka, za pomocą którego zostały one wyciśnięte, dysponent używał więc ewidentnie co najmniej od 1455 aż do śmierci w 1474 r. Śladów po jego pieczęciach zachowało się jednak więcej.

Jan Zamoyski, w latach 1569-1572 porządkujący i inwentaryzujący archiwum koronne jako ówczesny sekretarz królewski, natrafił na dwa odciski pieczęci Jana Hinczy z czasów podskarbińskich, z których jeden wisiał przy bliżej nieznanym dokumencie wystawionym przez niego w 1457 r., drugi zaś uwierzytelniał - wraz z pieczęciami licznych dygnitarzy koronnych - dokument króla Kazimierza Jagiellończyka z 17 VI 1451 potwierdzający statut żupny Kazimierza Wielkiego. Przy tym ostatnim dodał informację, że eksponował herb Działosza ${ }^{21}$, natomiast wiadomość o młodszym egzemplarzu wzbogacił schematycznym rysunkiem widniejącego na nim herbu, który wyobrażał jeleni róg od prawej i orle skrzydło od lewej strony tarczy, a zatem znów Działoszę ${ }^{22}$. Na tej podstawie nie sposób rzecz jasna stwierdzić, czy chodzi tu o odciski pieczęci pochodzące z jednego typariusza i czy był on tożsamy z tym, który posłużył Janowi Hinczy do wykonania odcisków znanych z lat 1455-1474, czy też używał on kilku różnych tłoków pieczęci, co było w tym czasie przez szlachtę koronną stosunkowo często praktykowane ${ }^{23}$. Ale nie ma to większego znaczenia dla dalszych rozważań, które w centrum zainteresowania stawiają sam herb. Ten zaś - klasyczna Działosza, tj. z jelenim rogiem po prawej i orlim skrzydłem po lewej stronie tarczy - na wszystkich zestawionych dotąd pieczęciach był taki sam.

Z 4 VII 1435 pochodzi dokument wystawiony przez Jana Hinczę w Legnicy, a więc podczas jego pobytu na Śląsku, w którym zaprzysiągł Ludwikowi II, księciu brzeskiemu i legnickiemu, zobowiązanie,

${ }^{18}$ Inwentarz odlewów pieczęci przekazanych przez F. Piekosińskiego przechowywany w Lwowskiej Narodowej Naukowej Bibliotece Ukrainy im. W. Stefanyka, Oddział Rękopisów, f. 54. Zdigitalizowana kopia inwentarza dostępna w Archiwum BOss., Dział IV: Księgi, nr 71 oraz < https://dbc.wroc.pl/dlibra/publication/2706/edition/2712/content> [dostęp: 30.03.2021]. Opis pieczęci Jana Hinczy w inwentarzu pod nr. 638.

${ }_{19}$ F. Piekosiński, Heraldyka polska wieków średnich, Kraków 1899, s. 49, nr 21.

${ }^{20} \mathrm{~W}$ odczycie legendy, najpewniej omyłkowo, pojawiły się o dwa dywizory za dużo, jeden na początku, drugi zaś w predykacie dysponenta pieczęci, rozdzielając go niepotrzebnie na dwie części. Mylnie zinterpretowano też $w$ jako $v$.

${ }^{21}$ Jana Zamoyskiego notaty heraldyczno-sfragistyczne, wyd. F. Piekosiński, Studia, Rozprawy i Materiały z Dziedziny Historii Polskiej i Prawa Polskiego, t. 7, Kraków 1907, nr 11, s. 19: „Est autem hoc sigillum Dzialossa in cera simplici, sine galea”. Sam dokument opublikowano w: VL, t. 1, wyd. J. Ohryzko, Petersburg 1859, s. 72-77, nr 174.

${ }^{22}$ Jana Zamoyskiego notaty, nr 50, s. 22: „ex litteris Hinczae de Rogow, castellani siradiensi, vicethesaurarii regni [...] sigillum eius in cera viridi”; J. Szymański, Herbarz, s. 120.

23 J. Wroniszewski, Średniowieczne pieczęcie rycerstwa polskiego, w: Pieczęcie w dawnej Rzeczypospolitej. Stan i perspektywy badań, red. Z. Piech, J. Pakulski, J. Wroniszewski, Warszawa 2006, s. 247-250; tenże, Pieczęcie polskie przy dokumentach horodelskich w świetle średniowiecznej sfragistyki, w: $1413 \mathrm{~m}$. Horodlès aktai (dokumentai ir tyrinëjimai). Akty horodelskie z 1413 roku (dokumenty i studia), red. J. Kiaupienė, L. Korczak, Vilnius-Kraków 2013, s. 149-150. 
że w razie nagłej śmierci władcy nie złoży hołdu jego następcy, dopóki ten nie wypłaci sum wiennych w wysokości 10 tys. kóp groszy praskich książęcym córkom, Magdalenie i Jadwidze ${ }^{24}$. Obecność Jana Hinczy u boku księcia brzesko-legnickiego nie budzi w świetle ostatnich badań nad rodziną Rogowskich zdziwienia. Jak bowiem przekonująco wykazano, przodkowie Jana Hinczy wywodzili się ze Śląska, gdzie w okolicach Środy Śląskiej i Namysłowa posiadali klucze majątkowe i gdzie w XV w. nadal siedzieli pieczętujący się Działoszą śląscy przedstawiciele familii, nazywani tutaj Salischami, piszący się z Chomiąży (Kumeise) i Zabora (Saabor), często występujący w źródłach z przydomkami Nassadel, Naßengrieff i Wende ${ }^{25}$. Tym, który w latach 80 . XIV w. przeniósł się do Korony, początkowo osiedlając się w leżącej przy granicy ze Śląskiem ziemi wieluńskiej, pozostającej do 1391 r. pod władzą księcia Władysława Opolczyka, był rycerz Hinczka z Roszkowic, ojciec Jana Hinczy ${ }^{26}$. Użyta w dokumencie z 1435 r. tytulatura w brzmieniu: Heyncze von Rogaw hewptmann zur Bresnicz auff Ketzerdorff przekonuje, że Rogowscy nie wyzbyli się swego śląskiego dziedzictwa. Wystawca pojawił się tutaj wszak nie tylko jako właściciel Rogowa, nabytego przez Hinczkę ok. 1396 r. i wyrosłego na główną siedzibę rodu w Królestwie, oraz starosta tenuty brzeźnickiej w ziemi sieradzkiej, ale także jako dziedzic Karłowic w księstwie brzeskim ${ }^{27}$. Był więc poddanym księcia Ludwika i w tym charakterze składał mu rzeczoną wyżej przysięgę. Władca z kolei musiał go darzyć niemałym zaufaniem. Niektórzy badacze sugerują, że zapracował on sobie na nie być może w trakcie misji, jaką przypuszczalnie odbył na Śląsk w przededniu nowego konfliktu zbrojnego z Krzyżakami w 1433 r. dla nawiązania sojuszniczych kontaktów przez króla polskiego z Ludwikiem brzesko-legnickim i zabezpieczenia $\mathrm{w}$ ten sposób spokoju na granicy polsko-śląskiej ${ }^{28}$. W lipcu 1435 r., w okresie między śmiercią króla Władysława (1 VI 1434) a zgonem księcia brzeskiego (30 IV 1436), na Śląsk ściągnęły jednak Jana Hinczę chyba sprawy prywatne, związane - jak należy sądzić - z regulacją rodzinnych kwestii majątkowych. Przeprowadził on bowiem wówczas przypuszczalnie transakcję sprzedaży Karłowic rycerzowi Samborowi z Błotnicy, który 30 VI 1438, już jako nowy właściciel wsi (Tschambor von Plottnytcz auf Ketzerdorf), przedsięwziął podobne zobowiązanie do tego, jakie w 1435 r. zaprzysiągł wobec księcia Ludwika i jego córek Jan Hincza ${ }^{29}$.

${ }^{24}$ Lehns- und Besitzurkunden Schlesiens und einzelnen Fürstenthümer im Mittelalter, t. 1, wyd. C. Grünhagen, H. Markgraf, Leipzig 1881 [dalej: LBUS, t. 1], nr 78, s. 381. O przysiędze wspomina B. Czwojdrak, Rogowscy, s. 27; taż, Między Śląskiem a Korona. Salisze i Działosze w XIV i XV wieku, w: Rody na Ślasku, Rusi Czerwonej i w Małopolsce. Średniowiecze i czasy nowożytne. Stan badań, metodologia, nowe ustalenia, red. W. Zawitkowska, A. Pobóg-Lenartowicz, Rzeszów 2010, s. 135, błędnie jednak podając, że Ludwik II był synem Ludwika I (w rzeczywistości był jego wnukiem, a synem Henryka [VIII] z Blizną) oraz przypisując Jadwidze siostrę Małgorzatę zamiast Magdaleny; zob. K. Jasiński, Rodowód Piastów śląskich. Piastowie wrocławscy, legnicko-brzescy, świdniccy, ziębiccy, głogowscy, żagańscy, oleśniccy, opolscy, cieszyńscy i oświęcimscy, wyd. 2 popr., wstęp do drugiego wyd. T. Jurek, Kraków 2007, s. 196-197, 204-205.

25 B. Czwojdrak, Rogowscy, s. 25-28; taż, Między Ślaskiem a Korona, s. 131-139; zob. też S. Kozierowski, Obce rycerstwo w Wielkopolsce w XII-XVI wieku, Poznań 1929, s. 32-33; J. Sperka, Otoczenie Władysława Opolczyka w latach 1370-1401. Studium o elicie władzy w relacjach z monarcha, Katowice 2006, s. 245-246; R. Żerelik, Szczepanów - stosunki własnościowe do 1945 roku, w: Od Franciszka Józefa do małych ojczyzn. Tom poświęcony pamięci Zbigniewa Frasa, red. M. Górny, Wrocław 2002, s. 11-18; tenże, Szczepanów. Wielkie dzieje dolnośląskiej wsi, Kraków-Wrocław 2018, s. 51-67.

${ }^{26}$ Obszernie na jego temat B. Czwojdrak, Rogowscy, s. 25-33, 36-47, 191-193; taż, Rycerz dwóch władców - Hinczka z Roszkowic herbu Działosza, w: Bunt wójta Alberta. Kraków i Opole we wzajemnych zwiazkach w XIV wieku, red. J. Rajman, Kraków 2013, s. 119-128. Jeśli chodzi o gniazdową wieś Hinczki, to istnieją problemy z jej identyfikacją. Badaczka genealogii Rogowskich brała pod uwagę zarówno dzisiejszy Raszków (niem. Raschkendorf) koło Środy Śląskiej, jak i dwie miejscowości o nazwie Roszkowice, jedną leżącą pod Byczyną, drugą zaś koło Namysłowa; taż, Rogowscy, s. 26-27; taż, Między Ślaskiem a Korona, s. 133; taż, Rycerz dwóch władców, s. 120.

27 J. Sperka, Otoczenie Władysława Opolczyka, s. 246, najpewniej omyłkowo, utożsamia tę wieś z Kotowicami (Katzendorf, Kottwitz).

${ }^{28}$ Tak B. Czwojdrak, Rogowscy, s. 62, przyp. 85. Hipotezy tej nie sposób ani potwierdzić, ani podważyć, gdyż nie zachowały się źródła wskazujące na bezpośrednie próby nawiązania współpracy między Władysławem Jagiełłą i Ludwikiem brzesko-legnickim, uchodzącym za wiernego stronnika Krzyżaków, z którymi zresztą próbował się wówczas układać przeciw Polsce. Nie ma jednak wątpliwości, że król podejmował zabiegi dyplomatyczne mające przeciągnąć na polską stronę książąt śląskich, choćby Henryka głogowskiego, Jana żagańskiego i Konrada Kąckiego; zob. P. Karp, Polsko-husycka wyprawa zbrojna przeciw Zakonowi Krzyżackiemu w roku 1433, Zielona Góra 2017, s. 93, 229.

${ }^{29}$ AP Wrocław, Dokumenty miasta Wrocławia, nr 2217; LBUS, t. 1, nr 87, s. 389. 
Wystawiony przez siebie podczas pobytu na Śląsku dokument z 4 VII 1435 uwierzytelnił Jan Hincza pieczęcią, która - jak wynika z uwag wydawców Colmara Grünhagena i Hermanna Markgrafa - przedstawiała „Adlerflügel und Hirschstange zusammengestellt”, a więc bez wątpienia godło Działoszów, choć z przedmiotami heraldycznymi zamienionymi miejscami, natomiast napis brzmiał: SIGILLV $(m)$ HEYNRICI DE ROGAWE ${ }^{30}$. O ile na podstawie lakonicznego opisu wizerunku nie sposób byłoby stwierdzić, czy mamy w tym wypadku do czynienia z pieczęcią wyciśniętą za pomocą tego samego tłoka, którego użycie potwierdzono co najmniej w latach 1455-1474, o tyle treść napieczętnej inskrypcji zdaje się wskazywać, że chodzi o zupełnie inne sigillum. Pewności mieć w tej kwestii jednak nie można, odczyty legend dokonane przez C. Grünhagena i H. Markgrafa często bowiem obarczone są błędami ${ }^{31}$. Weryfikację przynieść zatem mogła tylko autopsja oryginalnego odcisku stempla.

We wrocławskim archiwum pieczęć Jana Hinczy próbowała odnaleźć B. Czwojdrak w trakcie pracy nad monografią Rogowskich, ale podjęte przez nią „poszukiwania nie przyniosły pozytywnych rezultatów" ${ }^{32}$. Nie mogło być zresztą inaczej, skoro badaczka zbytnio zawierzyła, zdaje się, sporządzonemu przez Rościsława Żerelika, wytrawnego dyplomatyka i znawcę śląskich źródeł, katalogowi dokumentów przechowywanych w archiwach państwowych Dolnego Śląska, w którym odnotował on wprawdzie wspomniany wyżej dokument z 4 VII 1435 jako zachowany do dziś w zespole księstwa brzesko-legnicko-wołowskiego (Rep. 3), ale podał jednocześnie, że wisi przy nim na pergaminowym pasku pieczęć książęca ${ }^{33}$. Ustalenia te potwierdził Roman Stelmach w wydanej po 16 latach zaktualizowanej wersji katalogu, podając, że dyplom uwierzytelnia „pieczęć księcia Ludwika” [brzeskiego - M.L.W.] ${ }^{34}$. Rzecz to o tyle zaskakująca, że obaj badacze przywołali wcześniejszą, znaną nam już, XIX-wieczną edycję dokumentu, gdzie jako właściciel stempla występuje w legendzie Henryk z Rogowa, czyli nie kto inny tylko nasz Jan Hincza Rogowski. Hincza wszak to forma imienia Henryk, które na Śląsku zapisywano najczęściej w wersjach Heyncze, He(i)ncz(k)e, Hyncze ${ }^{35}$, a więc tak jak w intytulacji interesującego nas dokumentu (Heyncze von Rogaw).

Pieczęć, zawieszona na pergaminowym pasku, zachowała się w nadspodziewanie dobrym stanie, choć ma nieznacznie zatartą powierzchnię, co w niewielkim stopniu utrudnia odczyt legendy. Została wyciśnięta w ciemnym wosku w miseczce $\mathrm{z}$ wosku w kolorze naturalnym. Jest okrągła, a jej średnica wynosi odpowiednio ok. $26 \mathrm{~mm}$ (sam odcisk stempla) i $38 \mathrm{~mm}$ (cała pieczęć wraz z miseczką ochronną). W polu pieczętnym wyobrażono gotycką tarczę herbową typu hiszpańskiego, ozdobioną po zewnętrznej stronie trzema trójlistnymi koniczynkami (jedną od czoła i po jednej z każdego boku), okoloną trójlistną rozetą przeplecioną przez trójdzielną wstęgę, na której umieszczono inskrypcję rytą literami minuskuły gotyckiej w brzmieniu: sigillu $(m)$ / heyncze / de r[oga]we /. Na tarczy widnieją orle skrzydło (po prawej heraldycznie stronie) i róg jeleni o pięciu rosochach (po lewej), ten ostatni w słup na opak (zob. il. 3). Mamy więc tu do czynienia ewidentnie $\mathrm{z}$ herbem Działosza, tyle że odmienionym. Tak godło, jak i legenda, błędnie - jak się okazuje - odczytana przez wydawców dokumentu ${ }^{36}$, jednoznacznie identyfikują dysponenta sigillum. Nie był nim, wbrew R. Stelmachowi i R. Żerelikowi, książę brzeski Ludwik, ale Jan Hincza z Rogowa. Pozwalają też bezsprzecznie stwierdzić, że do uwierzytelnienia

${ }^{30}$ LBUS, t. 1 , nr 78, s. 381.

${ }^{31}$ Mylnie odczytane przez nich legendy na pieczęciach rycerskich zob. M.L. Wójcik, Pieczęcie rycerstwa śląskiego w dobie przedhusyckiej, t. 1-2, Kraków-Wrocław 2018, nr 1, 102, 109, 131, 240, 522, 661, 827, 838, 878, 881.

32 B. Czwojdrak, Rogowscy, s. 20, przyp. 24.

33 AP Wrocław, Rep. $3 \mathrm{nr} 32$ (28); Katalog dokumentów przechowywanych w archiwach państwowych Dolnego Śląska, t. 9: Archiwa ksiązęce i drobne akcesje, cz. 1: 1401-1500, oprac. R. Żerelik, Wrocław 1998, nr 295 i w indeksie (s. 153, 163, 177). Należy dodać, że leżąca pod Opatowcem wieś gniazdowa Rogowskich została tutaj błędnie zidentyfikowana jako Rogów Legnicki, Brzeźnica jako Brzeżnica alias Brzeźnica koło Ząbkowic (Śląskich), Karłowice natomiast raz poprawnie jako wieś w gminie Popielów, innym razem zaś jako Kaczorów pod Bolkowem (prawdopodobnie na skutek niefortunnego pomylenia Keczerdorf/Kertzendorf [= Karłowice] z Ketschdorf [= Kaczorów]).

${ }^{34}$ R. Stelmach, Katalog średniowiecznych dokumentów przechowywanych w Archiwum Państwowym we Wrocławiu, Wrocław-Racibórz 2014, nr 9410, z błędną informacją, że wystawcą dokumentu był rycerz Heyncze z Rogowa Legnickiego.

${ }_{35}$ H. Reichert, Die deutschen Familiennamen nach Breslauer Quellen des 13. und 14. Jahrhunderts, Breslau 1908, s. 7-8.

${ }^{36}$ LBUS, t. 1, nr 78, s. 381. 
dokumentu posłużył się on tłokiem innym od tego, którego użycie poświadczono dowodnie co najmniej w latach 1455-1474. Był zatem właścicielem co najmniej dwóch typariuszy, utrzymanych w tej samej, stosunkowo rzadko spotykanej wśród szlachty koronnej, konwencji plastycznej, zwłaszcza gdy chodzi o sposób wyeksponowania napieczętnej legendy. Jej sfragistykę zdominował bowiem w tym czasie, powszechny także w krajach ościennych (Czechy, Węgry, Prusy krzyżackie), motyw tarczy herbowej albo położonej tradycyjnie na wprost bez żadnych dodatkowych elementów lub ujętej w trójłukowe obramowanie, albo przedstawionej w ukłonie heraldycznym i wpisanej w wydłużoną wertykalnie czterolistną rozetę, z dodatkiem hełmu, klejnotu i labrów, przy czym w każdym z tych przypadków z inskrypcją rytą wzdłuż krawędzi stempla ${ }^{37}$.

Śląska pieczęć Jana Hinczy przynosi nieznany w Koronie wizerunek herbu Działosza. Staropolskie herbarze koronnej szlachty zgodnie bowiem podają, że herb ten wyobraża jeleni róg o pięciu rosochach i orle skrzydło ${ }^{38}$. Róg kładziony jest zatem konsekwentnie po prawej heraldycznie stronie, a skrzydło - po lewej. Układ taki dokumentują już najstarsze źródła heraldyki polskiej, mianowicie Długoszowe Insignia seu clenodia Regis et Regni Poloniae i herbarz arsenalski, będący powstałą w XVI w. i wzbogaconą o barwne rysunki herbów redakcją dzieła Długosza ${ }^{39}$. Współczesny Janowi Hinczy, bo pochodzący z lat 1464-1480 przekaz Długosza ${ }^{40}$, który znał podskarbiego najpewniej osobiście, można jednak odnieść wyłącznie do wizerunku, jaki przynoszą pieczęcie Jana Hinczy z lat 1451-1474. Odpowiada mu wszak widniejący na nich układ elementów składowych godła z jelenim rogiem po prawej (heraldycznie) stronie i orlim skrzydłem po lewej. W schemat ten nie wpisuje się natomiast pieczęć śląska zdradzająca spore umiejętności rytownicze artysty, na której doszło nie tylko do przestawienia przedmiotów heraldycznych w osi poziomej (róg i skrzydło zamieniły się miejscami), ale także do odwrócenia w pionie jeleniego rogu (na opak). Konwersje te można oczywiście przypisywać pomyłce twórcy tłoka, ale można też doszukiwać się w nich świadomej ekspozycji znaku o ściśle określonych konotacjach, innych niż przypisywane znanej powszechnie formie utrwalonej w heraldyce polskiej.

Należy zauważyć, że za najstarszą w Koronie pieczęć z herbem Działosza uznaje się w historiografii sigillum przywieszone do dokumentów unii horodelskiej z $1413 \mathrm{r}$. Herb ten przyjął wówczas - wraz z chrześcijańskim imieniem Piotr - bojar litewski Wołczko Rokutowicz, uczestnik bitwy pod Grunwaldem, późniejszy starosta chełmski (1429-1430, 1443-1444) i podkomorzy lwowski (1434-1453) $)^{41}$ Nie znamy natomiast imienia rycerza adoptującego litewskiego bojara ${ }^{42}$, ale zważywszy na fakt, że pierwszymi poświadczonymi w Koronie przedstawicielami Działoszów byli Hinczowie (Rogowscy), ze względów chronologicznych w grę wchodzić może jedynie Henryk (ur. po 1388, zm. przed 25 II 1426),

37 J. Wroniszewski, Średniowieczne pieczęcie, s. 246-247; tenże, Pieczęcie polskie, s. 149-150. O zwyczajach heraldycznych w sfragistyce rycerstwa polskiego zob. tenże, Herby rycerskie w średniowiecznej sfragistyce polskiej, w: Pieczęcie herbowe - herby na pieczęciach, red. W. Drelicharz, Z. Piech, Warszawa 2011, s. 227-250.

38 Wielu autorów mylnie pisze jednak o skrzydle sępa; zob. B. Paprocki, Gniazdo cnoty, Kraków 1578, k. 904; tenże, Herby rycerstwa polskiego na pięcioro ksiagg rozdzielone, Kraków 1584, s. 259; M. Bielski, Kronika polska, wyd. J. Bielski, Kraków 1597, s. 269; S. Nakielski, Miechovia sive promptuarium antiquitatum Monasterii Miechoviensis, Cracoviae 1634, s. 69; S. Okolski, Orbis Polonus, t. 1, Cracoviae 1641, s. 195; P. Nałęcz Małachowski, Zbiór nazwisk szlachty z opisem herbów własnych familiom zostajacym w Królestwie Polskim i Wielkim Xięstwie Litewskim, Lublin 1805, s. 599; K. Niesiecki, Herbarz polski, wyd. J.N. Bobrowicz, t. 3, Lipsk 1841, s. 445; zob. też B. Czwojdrak, Między Śląskiem a Korona, s. $132-133$.

39 Klejnoty, s. 61; Stemmata Polonica. Rękopis nr 1114 Klejnotów Dlugosza w Bibliotece Arsenatu w Paryżu, wyd. H. Polaczkówna, „Prace Sekcyi Historyi Sztuki i Kultury Towarzystwa Naukowego we Lwowie”, 1, 1927, z. 2, s. 200.

${ }^{40} \mathrm{Na}$ ten właśnie okres datuje się w historiografii spisanie przez Długosza Klejnotów; zob. Klejnoty, s. $28-31$.

${ }^{41}$ Akta unii Polski z Litwa 1385-1791, wyd. S. Kutrzeba, W. Semkowicz, Kraków 1932, nr 49, s. 50-54 (zwł. s. 54); nr 50, s. 55-59 (zwł. s. 56); W. Semkowicz, O litewskich rodach bojarskich zbratanych z szlachta polska w Horodle w 1413 r. (ciag dalszy), Rocz. Herald., 7, 1924-1925, s. 217-218; 1413 m. Horodless aktai, s. 19-35 (zwł. s. 20, 23, 26, 29, 32, 34). O Piotrze Rokutowiczu zob. szerzej W. Czarnecki, Bojarzy litewscy w ziemi chelmskiej. Wołczkowie herbu Działosza do początku XVI w., „Res Historica”, 32, 2011, s. 23-26; tenże, Szlachta ziemi chetmskiej do połowy XVI wieku, Białystok 2012, s. 302-305 i tabl. XVII (s. 397).

${ }^{42}$ Imienne zestawienie uczestników zjazdu w Horodle sporządziła A. Sochacka, Możnowładcy polscy wobec unii horodelskiej, „Średniowiecze Polskie i Powszechne”, 3, 2004, tab. na s. 125-126; zob. też E. Rimša, Akta horodelskie a heraldyka litewskich bojarów, w: 1413 m. Horodles aktai, tab. 1, poz. 23. 
najstarszy brat Jana Hinczy. Ich ojciec bowiem, podskarbi królewski Hinczka z Roszkowic, który przeniósł się na ziemie Królestwa Polskiego ze Śląska, zmarł najpóźniej w listopadzie 1411 r., Henryk zaś należał w drugiej dekadzie XV stulecia do grona osób z najbliższego otoczenia Władysława Jagiełły: pod Grunwaldem był członkiem straży przybocznej monarchy, w 1413 i 1415 r. piastował urząd krajczego, a w 1419 r. awansował na królewskiego podskarbiego ${ }^{43}$. Przy aktach horodelskich nie zachowały się oryginalne odciski pieczęci z herbem Działosza, nie wiadomo zresztą, czy do dokumentu strony polskiej (tzw. adopcyjnego) takowy został w ogóle przywieszony ${ }^{44}$, ale wspomniany już wyżej Jan Zamoyski sporządził odrys herbu widocznego na stemplu uwierzytelniającym dokument strony litewskiej, który przedstawiał orle skrzydło w słup i jeleni róg w słup na opak ${ }^{45}$. Zdolności plastyczne królewskiego sekretarza nie były największe ${ }^{46}$, stąd też nie ma pewności, że rysunek oddaje wiernie stan faktyczny. Rzecz wszakże nie w szczegółach wizerunku, ale w ogólnym układzie elementów składowych godła, ten zaś - orle skrzydło po prawej i jeleni róg na opak po lewej stronie tarczy - zdaje się potwierdzać towarzyszący rysunkowi opis herbu w brzmieniu: ,sigillum alae cum cornu cerui, videtur esse Dzialossa"47. Układ ten, zwłaszcza zaś obrócenie jeleniego rogu na opak, musiało chyba wywołać u Zamoyskiego niemałe wątpliwości identyfikacyjne, skoro nie nazwał widocznego na pieczęci herbu wprost Działoszą, tylko pisał o nim „videtur esse Dzialossa”.

Porządek figur heraldycznych oraz ich ułożenie trudno uznać tutaj za przypadkowe, zwłaszcza w zestawieniu z pieczęcią Jana Hinczy z 1435 r. Co prawda nie wiadomo, czy swą pieczęć przywiesił przy aktach horodelskich Wołczko (Piotr) Rokutowicz, czy też polski sygnatariusz jego adopcji ${ }^{48}$, prawdopodobnie Henryk Rogowski, i która z nich eksponowała wizerunek herbu Działosza odwzorowany przez Zamoyskiego, ale nie ma to większego znaczenia. Niezależnie bowiem od tego, kto był dysponentem herbu, przyjmował on bez wątpienia postać używaną zarówno przez adoptowanego w Horodle bojara, który przecież musiał zlecić wcześniejsze wykonanie typariusza, jak i przez udzielającego mu go przedstawiciela rodu Działoszów. A skoro herb ten wykazuje tożsamość co do treści i układu godła z herbem widniejącym na pieczęci Jana Hinczy z 1435 r., można chyba założyć, że w identycznym kształcie posługiwał się nim już Hinczka z Roszkowic, protoplasta Rogowskich. Zważywszy zaś na pochodzenie tego ostatniego ze Śląska, to właśnie tam należałoby poszukiwać korzeni owego heraldycznego wyobrażenia ${ }^{49}$.

Najstarszy na Śląsku (i najstarszy w ogóle) znany dziś wizerunek herbu Działosza pojawił się na pieczęci wyciśniętej przez jednego z przedstawicieli Salischów przy dokumencie z 1369 r., a więc jeszcze przed przenosinami Hinczki z Roszkowic do ziemi wieluńskiej ${ }^{50}$. Jej dysponentem był Grzegorz Wende z Chomiąży koło Środy Śląskiej, brat Hansa (Jana) Wende, uczestnika (po stronie krzyżackiej) bitwy pod Grunwaldem, notowany w źródłach w latach 1358-139251. Eksponowany na sigillum

${ }^{43}$ O Henryku pisała obszernie B. Czwojdrak, Rogowscy, s. 48-52, 193-194. Również tamże, s. 191-192, korekta daty śmierci Hinczki z Roszkowic, mylnie kładzionej dotąd przez badaczy na rok 1416.

44 J. Wroniszewski, Pieczęcie przy dokumencie adopcyjnym polskiej szlachty z 1413 r., w: 1413 m. Horodlès aktai, s. 321-358; E. Rimša, Pieczęcie dokumentu bojarów litewskich z 1413 r., w: tamże, s. 442-443.

${ }^{45}$ AGAD, Archiwum Zamoyskich, sygn. 33, s. 653. Rycinę tę reprodukują O. Odnorozhenko, Rodova heral'dyka Rus'koho korolivstva ta Rus 'kykh zemel' Korony Pol's 'koï XIV-XVI st., Kharkiv 2009, s. 172, ryc. 396; E. Rimša, 1413 m. Lietuvos bajoru dokumentu antspaudai, w: 1413 m. Horodlès aktai, il. 2, s. 422.

46 S. Kutrzeba i W. Semkowicz, w: Akta unii Polski z Litwa, s. 56, nazywają rysunek Zamoyskiego wręcz „niedołężnym”.

${ }^{47}$ AGAD, Archiwum Zamoyskich, sygn. 33, s. 653; Jana Zamoyskiego notaty, nr 76, s. 24.

${ }^{48}$ P. Rabiej, Dokumenty unii horodelskiej, w: 1413 m. Horodlès aktai, s. 101; E. Rimša, Pieczęcie dokumentu bojarów litewskich, s. 442-443. Nie wszystkim uczestnikom zjazdu udało się wszak dotrzeć do Horodła, a z powodu nieobecności przedstawicieli jednej ze stron, czy to Litwinów, czy Polaków, unijne dokumenty pieczętowali za nich przedstawiciele drugiej strony; zob. E. Rimša, Akta horodelskie a heraldyka, s. 219. Wołczkowi Rokutowiczowi przypisuje tę pieczęć jednoznacznie O. Odnorozhenko, Rodova heral'dyka, s. 172.

49 Tak właśnie czynią T. Jurek, w: „Genealogia. Studia i Materiały Historyczne”, 4, 1994, s. 144 (w recenzji herbarza średniowiecznego rycerstwa polskiego autorstwa J. Szymańskiego, zob. wyżej, przyp. 15) oraz B. Czwojdrak, Rogowscy, s. 23-24 i przyp. 6 (s. 24); taż, Między Śląskiem a Korona, s. 132.

${ }^{50}$ Pieczęć tę reprodukuje i opisuje M.L. Wójcik, Pieczęcie rycerstwa śląskiego, t. 2, nr 664.

${ }^{51}$ Regesty ślaskie, red. W. Korta, t. 4: 1358-1359, oprac. J. Gilewska-Dubis, K. Bobowski, Wrocław-Warszawa [1992], nr 211-212, 464, 483, 501-503, 532, 571, 586, 601, 636, 637; t. 5: 1360, oprac. J. Gilewska-Dubis, Wrocław-Warszawa 
tego rycerza herb przedstawia orle skrzydło i jeleni róg, zaprzeczając ewidentnie przekonaniu Conrada Blažka i Romana Sękowskiego, jakoby godłem panów piszących się z przydawką posesjonatywną delvon Kumeise (z Chomiąży) było jelenie poroże ${ }^{52}$. Oba reprezentatywne dla Działoszów motywy heraldyczne, mianowicie skrzydło i róg, umieszczono na jednolitej tarczy, przy czym orle skrzydło po prawej, a jeleni róg po lewej stronie, czyli w układzie identycznym z tym, z jakim mamy do czynienia na pieczęciach należących do sygnatariusza dokumentu unii horodelskiej (Wołczka Rokutowicza lub Henryka Rogowskiego) i Jana Hinczy z 1435 r. Różni je natomiast orientacja jeleniego rogu, który na pieczęci Grzegorza z Chomiąży nie został odwrócony na opak. Z 1418 r. pochodzi zaś pieczęć należąca do Piotra Działoszy (Petrasch Dzalusch), rycerza z otoczenia księcia oleśnickiego Konrada, przedstawiciela innej, używającej nazwiska Nassengneff (Nassengrieff, Naßengrieff), gałęzi śląskich Działoszów (Salischów), na której widnieje z kolei herb z jelenim rogiem po prawej i orlim skrzydłem po lewej stronie $^{53}$, a więc w układzie takim, jaki po raz pierwszy wystąpił na omówionych wyżej pieczęciach Jana Hinczy z lat 1451-1474. I choć bez kwerendy archiwalnej nie sposób prześledzić późniejszej ikonografii interesującego nas herbu, gdyż nie dysponujemy - jak na razie - inwentarzami, katalogami i opracowaniami śląskich pieczęci rycerskich (szlacheckich) z XV i XVI w., niemniej na podkreślenie zasługuje fakt, że nowożytne dzieła genealogiczno-heraldyczne na temat śląskiej szlachty - za wyjątkiem herbarza Crispina i Johanna Scharffenbergów z 1578 r., w którym doszło ewidentnie do omyłkowej zamiany miejscami elementów godła ${ }^{54}$ - kładą konsekwentnie w herbie Salischów orle skrzydło po prawej i jeleni róg po lewej stronie jednolitej bądź dzielonej w słup tarczy ${ }^{55}$.

$\mathrm{Na}$ podstawie tej wątłej podstawy źródłowej trudno co prawda formułować daleko idące wnioski, ale nie sposób kwestionować ikonograficznej tożsamości najstarszej (z 1369) i ostatecznej (nowożytnej) wersji herbu śląskich Działoszów (Salischów), bez względu na to, czy chodzi o linię średzką (Wende), czy też oleśnicko-namysłowską (Nassengneff). Herb znany z pieczęci Piotra należałoby traktować w związku z tym jako przejaw dostrzeżonego w historiografii, aczkolwiek wciąż jeszcze niedostatecznie rozpoznanego, zjawiska polegającego na odróżnianiu odrębnych linii niektórych rodzin mniej lub bardziej odmienionymi herbami ${ }^{56}$. To, co nas tu jednak najbardziej interesuje, to wyraźnie widoczne

[1992], nr 151, 254-256; Landbuch księstw świdnickiego i jaworskiego, wyd. T. Jurek, t. 1: 1366-1376, Poznań 2004, nr 73, 591; t. 2: 1385-1395, Poznań 2000, nr 1057; Das Soldbuch des Deutschen Orden 1410-1411, wyd. S. Ekdahl, cz. 2: Indices mit personengeschichtlichen Kommentaren, Köln-Weimar-Wien 2010, s. 265; zob. też R. Żerelik, Szczepanów, s. 67 (tutaj podwójnie błędna identyfikacja, najpierw Henryka Działoszy, syna Hinczki z Roszkowic, z rycerzem herbu Wadwicz, a następnie herbu Wadwicz ze śląskim herbem Salisch).

52 Der Abgestorbene Adel der Preussischen Provinz Schlesien, t. 3, oprac. C. Blažek, J[ohann] Siebmacher's grosses und allgemeines Wappenbuch in einer neuen, vollständig geordneten und reich vermehrten Auflage mit heraldischen und historisch-genealogischen Erläuterungen, t. 6, dział 8, Nürnberg 1894, s. 139-140 i tabl. 91; R. Sękowski, Herbarz szlachty ślaskiej. Informator genealogiczno-heraldyczny, t. 4, Chorzów 2005, s. 158.

${ }^{53}$ M.L. Wójcik, Pieczęcie rycerstwa śląskiego, t. 2, nr 665. Warto dodać, że ta właśnie gałąź Salischów, zwana w polskiej literaturze Nasięgniewicami, dała początek przemyskiej linii Działoszów, która od należącej do niej wsi Młodowice pod Przemyślem przybrała nazwisko Młodowickich; zob. o nich B. Czwojdrak, Młodowiccy herbu Działosza. Przyczynek do dziejów szlachty w ziemi przemyskiej w XV w., w: Mieszczanie, wasale, zakonnicy, red. B. Śliwiński, Studia z Dziejów Średniowiecza, t. 10, Malbork 2004, s. 47-59.

${ }^{54}$ Schlesisches Wappenbuch von Crispin und Johann Scharffenberg, wyd. H. von Mosch, Neustadt an der Aisch 1984, tabl. 234. Jest to edycja niemalowanego egzemplarza herbarza przechowywanego w Österreichische Nationalbibliothek w Wiedniu. Tymczasem barwiony egzemplarz tego dzieła, dostępny online $(<$ https://digital.staatsbibliothek-berlin.de/ werkansicht?PPN=PPN803782608\&DMDID =DMDLOG_0003\&PHY SID=PHYS_0015> [dostęp: 1.05.2019]), znajduje się w zbiorach Staatsbibliothek Preußischer Kulturbesitz w Berlinie, Sammlung 16. Jahrhundert, sygn. 177280, fol. 162r. Pomyłki, czy to w układzie elementów godła, czy to w barwach pól zdarzały się Scharffenbergom stosunkowo często, czego przykładem mogą być m.in. herby Buchwitzów, Gersdorfów, Kalckreuterów, Mühlheimów, Tschammerów i Tschischwitzów.

55 Zob. m.in.: Johann Siebmachers Wappenbuch von 1605, wyd. H. Appuhn, München 1999, s. 78, 88; F. Lucae, Schlesiens curiöse Denckwürdigkeiten oder vollkommene Chronica von Ober- und Nieder-Schlesien welche in Sieben Haupt-Theilen vorstellet [...], Frankfurt am Main 1689, s. 1840; J. Sinapius, Schlesische Curiositäten erste Vorstellung Darinnen die ansehnlichen Geschlechter des Schlesischen Adels. Mit Erzehlung des Ursprungs, der Wappen, Genealogien, der qualificirtesten Cavaliere, der Stamm-Hausler und Guter beschrieben, t. 1, Leipzig 1720, s. 661-662, 795.

${ }^{56} \mathrm{O}$ procesach heraldyzacji godeł rycerstwa śląskiego pisali m.in.: T. Jurek, Zmienność herbów rycerzy niemieckich na Śląsku, Rocz. Herald., nowa seria, 2 (13), 1995, s. 41-51; M.L. Wójcik, Herby, hetmy i klejnoty. Uniwersalne i swoiste treści 
podobieństwa w zakresie doboru treści heraldycznych między śląskimi i koronnymi Działoszami, przy czym jeśli za pierwowzór herbu Działosza uznać, jako formę pierwotną, herb panów z Chomiąży, niewątpliwych antenatów Rogowskich, to do momentu osiągnięcia swej klasycznej postaci, znanej zarówno z pieczęci Jana Hinczy z lat 1451-1474, jak i z opisu Jana Długosza, musiał zostać dwukrotnie poddany modyfikacji. Najpierw objęła ona przeorientowanie położenia jeleniego rogu na opak, a następnie jego ponowne obrócenie, $\mathrm{z}$ jednoczesną zamianą miejscami elementów składowych godła, co upodobniło Działoszę do znaku eksponowanego na pieczęci Piotra von Nassengneff z 1418 r. Impulsem do pierwszej, potwierdzonej przy akcie unii horodelskiej i na pieczęci Jana Hinczy z Rogowa z 1435 r., mogły być przenosiny Hinczki z Roszkowic do ziemi wieluńskiej. Drugą, którą przypisać należy inicjatywie Jana Hinczy, spowodował najpewniej jego awans do grona osób tworzących elitę urzędniczą monarchii. Wprowadzoną przez niego wersję rychło zaadaptowali przedstawiciele wszystkich osiadłych (i rozrodzonych) w Koronie linii Działoszów, reprezentowanych wprawdzie przeważnie przez drobne rycerstwo, ale zdradzających polityczne aspiracje dorównujące społecznej pozycji Rogowskich. Przekonywać zdaje się o tym sigillum należące do Piotra Wołczkowica, podsędka ziemi chełmskiej, syna (i imiennika) znanego nam już bojara litewskiego z 1413 r., uwierzytelniające dokument z 14 VI 1456, a więc współczesne pieczęciom Jana Hinczy ${ }^{57}$. O ile bowiem jego ojciec kładł na tarczy orle skrzydło i jeleni róg na opak, o tyle on sam przyjął układ taki, jaki widnieje na młodszym sigillum Jana Hinczy. Herb z jego pieczęci przedstawia bowiem tarczę rycerską typu niemieckiego (z wycięciem na kopię), a na niej jeleni róg po prawej stronie i orle skrzydło po lewej; z legendy, rytej minuskułą gotycką, zachowanej wprawdzie w całości, ale dziś już niewyraźnej, udaje się odszyfrować jedynie incipit w brzmieniu:

* $\mathrm{s} \star \operatorname{vol}[\ldots]^{58}$ (zob. il. 4). Proces heraldyzacji herbu Działosza przebiegał więc według rozpoznanego w historiografii schematu polegającego na przejmowaniu wzorców ikonograficznych kreowanych przez najwybitniejsze jednostki bądź rodziny w obrębie rodu heraldycznego $0^{59}$.

Niedostrzeżona w badaniach nad heraldyką rycerstwa polskiego pieczęć Jana Hinczy z 1435 r., odnaleziona w źródłach śląskiej proweniencji, wydatnie wzbogaca naszą dotychczasową wiedzę o herbie Działosza. Przede wszystkim pozwala zakwestionować przekonanie, że przedstawiał on niezmiennie jeleni róg po prawej i orle skrzydło po lewej stronie tarczy. Dowodzi też bezpodstawności twierdzenia, że herby śląskich Salischów i - słusznie wyprowadzanych z tej familii - koronnych Działoszów były identyczne. O ile analogie między nimi w zakresie doboru tożsamych elementów godła zdają się nie pozostawiać wątpliwości co do ich wspólnych korzeni, o tyle różnice w sposobie ekspozycji jeleniego rogu i orlego skrzydła wskazują, że ostateczna forma herbu Działosza, znana zarówno z pieczęci podskarbiego koronnego Jana Hinczy z Rogowa z lat 1451-1474 i datowanego na lata 1464-1480 przekazu Jana Długosza, jak również z nowożytnych herbarzy polskiej szlachty, ukształtowała się w drodze stopniowej ewolucji. Polegała ona na - co najmniej dwukrotnej - modyfikacji położenia i układu dwóch, ciągle tych samych, przedmiotów heraldycznych (orlego skrzydła i jeleniego rogu, w takiej właśnie pierwotnie kolejności, zaczynając od prawego boku tarczy), z których ostatnią, wprowadzoną przez Jana Hinczę, datować należy na okres po 4 VII 1435 i przed 17 VI 1451. Jej przyswojenie przez inne

obrazowe pieczęci rycerstwa śląskiego, w: Wokół znaków i symboli. Herby, pieczęcie i monety na Pomorzu, Śląsku i Ziemi Lubuskiej do 1945 roku, red. A. Chlebowska, A. Gut, Warszawa 2008, s. 49-66; tenże, Od hetmu do herbu-przyczynek do badań nad heraldyzacja znaku rycerstwa ślaskiego, w: Pieczęcie herbowe, s. 251-271. Materiał sfragistyczny dokumentujący zmiany herbów niektórych herbów rodzin rycerskich w okresie do lat 20. XIV w. zestawił tenże, Pieczęcie rycerstwa ślaskiego, t. 1-2, passim.

${ }^{57}$ AN, Zbiór Rusieckich. Dokumenty pergaminowe, nr 140. Przerys tej pieczęci opublikował O. Odnorozhenko, Rodova heral'dyka, s. 172, ryc. 397. Informacje o jej dysponencie zebrał W. Czarnecki, Bojarzy litewscy, s. 26, 30-33; tenże, Szlachta ziemi chetmskiej, s. 305, 310-313 i tabl. XVII (s. 397).

${ }^{58}$ Jego pieczęć, najpewniej ta sama, uwierzytelniała także akt lwowskiej konfederacji szlachty z 1464 r., o czym O. Odnorozhenko, Rodova heral'dyka, s. 173. Tutaj także opis pieczęci Piotra z 1456 r.

${ }^{59} \mathrm{Na}$ ten temat wypowiedział się szerzej J. Bieniak, Heraldyka polska przed Dlugoszem. Uwagi problemowe, w: Sztuka i ideologia XV wieku. Materiały sympozjum Komitetu Nauk o Sztuce Polskiej Akademii Nauk, Warszawa, 1-4 grudnia 1976 r., red. P. Skubiszewski, Warszawa 1978, s. 187-192. Zob. też interesujące rozważania M. Gigonia, Znikajace znaki. Czy można prześledzić losy polskich herbów rycerskich w świetle źródet średniowiecznych?, „Ogrody Nauk i Sztuk”, 2, 2012, s. 253-262. 
linie rodu, potwierdzone w szczątkowo zachowanym materiale sfragistycznym od 1456 r., zdaje się świadczyć, że proces heraldyzacji herbu Działosza, posiadającego odtąd walor trwałego ikonograficznie dziedzicznego znaku przynależności rodowej, dobiegł końca.

\section{The Silesian seal of Jan Hincza of Rogów from 1435. A contribution to the history of Dzialosza coat of arms}

Streszczenie: Genealogists consider Crown Treasurer Jan Hincza of Rogów (c. 1400-1474) the most prominent and wealthiest representative of the Rogowski family of Działosza coat of arms. His long, public activity, spanning the years from 1440 to 1474 , was not reflected in the number of his surviving sphragistic artefacts. Historians have noted only two original prints, one drawn copy and one reference to the magnate's coat-of-arms seal from 1451-1466, showing the traditional depiction of the family coat of arms, with a stag's horn on the right and an eagle's wing on the left side of the shield, both palewise. A research query carried out by the author of this short study revealed two more impressions of Jan Hincza's seal, dated 1435 and 1473, and a reference to it under the year 1472. While the 1472 and 1473 stamp's impressions bear an image of the coat of arms identical to that on the stamps from 1451-1466, the 1435 seal, affixed to a document issued by Jan Hincza in Legnica, brings a hitherto unknown image of the Działosza coat of arms, in which the elements of the coat of arms are swapped, and the stag's horn is turned backwards. Its originality is indicated by a similar layout of the charge (only without the turned horn) on the seal of Grzegorz Wende of Chomiąża (1369), a member of the Silesian Salisch family, from which descended the Działosza family in the Crown, and by an identical layout (with the stag's horn turned backwards) on the seal of Wołczek (Piotr) Rokutowicz (1413), a Lithuanian boyar adopted at Horodło to the Działosza coat of arms. The stag's horn on the right and the eagle's wing on the shield's left side in the Działosza coat of arms appeared for the first time on Jan Hincza's seal (1451). The seal of Piotr, the son of Wołczek (Piotr) Rokutowicz (1456), reproduced the same scheme, which seems to confirm the thesis known in the literature on the adoption of iconographic patterns created by the most eminent individuals or families within a heraldic family. Therefore, the end of the heraldisation of the Działosza coat of arms should be placed in the middle of the fifteenth century.

Nota o autorze: Marek L. Wójcik, dr hab. nauk humanistycznych, adiunkt w Instytucie Historycznym Uniwersytetu Wrocławskiego. Zainteresowania naukowe koncentruje na naukach pomocniczych historii, zwłaszcza na dyplomatyce, genealogii, heraldyce i sfragistyce oraz na dziejach średniowiecznego Śląska. Ostatnio prowadzi badania nad pieczęciami i herbami śląskich rycerzy (do początków XV w.) oraz nad dolnośląską heraldyką samorządową.

Author: Marek L. Wójcik, PhD in Humanities, assistant professor at the Historical Institute of the University of Wrocław. He focuses his research interests on auxiliary sciences of history, especially diplomatics, genealogy, heraldry, and sphragistics, and on the history of medieval Silesia. Recently, he has been conducting research on seals and coats of arms of Silesian knights (until the early 15th century) and on Lower Silesian local government heraldry.

Instytut Historyczny

Uniwersytet Wrocławski

ul. Szewska 49

50-139 Wrocław

e-mail: marek.wojcik@uwr.edu.pl

\section{Bibliografia}

\section{Źródla drukowane}

Akta unii Polski z Litwa 1385-1791, wyd. S. Kutrzeba, W. Semkowicz, Kraków 1932

Jana Zamoyskiego notaty heraldyczno-sfragistyczne, wyd. F. Piekosiński, Studia, Rozprawy i Materiały z Dziedziny Historii Polskiej i Prawa Polskiego, t. 7, Kraków 1907

Klejnoty Dlugoszowe, oprac. i wyd. M. Friedberg, Rocz. Herald., 10, 1930, s. 1-119 
Lehns- und Besitzurkunden Schlesiens und einzelnen Fürstenthümer im Mittelalter, t. 1, wyd. C. Grünhagen, H. Markgraf, Leipzig 1881

Stemmata Polonica. Rękopis nr 1114 Klejnotów Dlugosza w Bibliotece Arsenału w Paryżu, wyd. H. Polaczkówna, „Prace Sekcyi Historyi Sztuki i Kultury Towarzystwa Naukowego we Lwowie”, 1, 1927, z. 2, s. 161-250

\section{Opracowania}

$1413 \mathrm{~m}$. Horodles aktai (dokumentai ir tyrinejimai). Akty horodelskie z 1413 roku (dokumenty i studia), red. J. Kiaupienè, L. Korczak, Vilnius-Kraków 2013

Czarnecki W., Bojarzy litewscy w ziemi chetmskiej. Wotczkowie herbu Działosza do poczatku XVI w., „Res Historica", 32, 2011, s. 23-26

Czarnecki W., Szlachta ziemi chetmskiej do polowy XVI wieku, Białystok 2012

Czwojdrak B., Jan Hincza z Rogowa - rycerz królowej Zofii, w: Faworyci i opozycjoniści. Król a elity polityczne w Rzeczypospolitej XV-XVIII wieku, red. M. Markiewicz, R. Skowron, Kraków 2006, s. 61-66

Czwojdrak B., Między Ślaskiem a Korona. Salisze i Dziatosze w XIV i XV wieku, w: Rody na Ślasku, Rusi Czerwonej $i$ w Małopolsce. Średniowiecze i czasy nowożytne. Stan badań, metodologia, nowe ustalenia, red. W. Zawitkowska, A. Pobóg-Lenartowicz, Rzeszów 2010, s. 131-139

Czwojdrak B., Rogowscy herbu Działosza - podskarbiowie królewscy. Studium z dziejów możnowładztwa w drugiej polowie XIV i w XV wieku, Katowice 2002

Czwojdrak B., Rycerz dwóch władców - Hinczka z Roszkowic herbu Dzialosza, w: Bunt wójta Alberta. Kraków i Opole we wzajemnych zwiazkach w XIV wieku, red. J. Rajman, Kraków 2013, s. 119-128

Grzegorz M., Analiza dyplomatyczno-sfragistyczna dokumentów traktatu toruńskiego 1466 r., Toruń 1970

Jurek T., Zmienność herbów rycerzy niemieckich na Ślasku, Rocz. Herald., nowa seria, 2 (13), 1995, s. 41-51

Kalinowska J., Jan Hincza z Rogowa i jego działalność fundacyjna na dworze pierwszych Jagiellonów, „Analecta Cracoviensia", 19, 1987, s. 319-341

Odnorozhenko O., Rodova heral'dyka Rus'koho korolivstva ta Rus'kykh zemel' Korony Pol's'koï XIV-XVI st., Kharkiv 2009

Piekosiński F., Heraldyka polska wieków średnich, Kraków 1899

Semkowicz W., O litewskich rodach bojarskich zbratanych z szlachta polska w Horodle w $1413 \mathrm{r}$. (ciag dalszy), Rocz. Herald., 7, 1924-1925, s. 210-220

Sperka J., Otoczenie Władystawa Opolczyka w latach 1370-1401. Studium o elicie wtadzy w relacjach z monarcha, Katowice 2006

Szymański J., Herbarz średniowiecznego rycerstwa polskiego, Warszawa 1993

Wójcik M.L., Pieczęcie rycerstwa ślaskiego w dobie przedhusyckiej, t. 1-2, Kraków-Wrocław 2018

Wroniszewski J., Herby rycerskie w średniowiecznej sfragistyce polskiej, w: Pieczęcie herbowe - herby na pieczęciach, red. W. Drelicharz, Z. Piech, Warszawa 2011, s. 227-250

Wroniszewski J., Średniowieczne pieczęcie rycerstwa polskiego, w: Pieczęcie w dawnej Rzeczypospolitej. Stan i perspektywy badań, red. Z. Piech, J. Pakulski, J. Wroniszewski, Warszawa 2006, s. 235-250 